\title{
Production assessment of Artemia Franciscana (imported species) with the local species of ghom province Artemia pond culture at the coast of ghom province (Iran) Namak Lake
}

\begin{abstract}
Artemia is a Crustacean of Artemidae family, whose importance has been realized as of year 1930 in the field of aquaculture as live food source. Whereas under current global conditions, Artemia cannot be harvested from its natural habitats, today growing the same is deemed as one of the main approaches to achieve such species, as the environmental and genetic factors as well as type of Artemia directly affect the growing of this species. In this study, 2 species of local Artemia from Ghom Province, A. parthenogenetica, were cultured together with imported species, A. franciscana, in 6 constructed ponds, each in 3 treatments along the coast of Ghom's Namak Lake for a 180-day period. The results indicate that cyst and biomass culture and production in the local specie are more suitable than the imported one and 80 and $66 \mathrm{~kg} /$ hectare of cyst were produced from Ghom's local and A. franciscana imported species, respectively. 2,800 and 2,200 $\mathrm{kg}$ of biomass were also achieved from Ghom's local and A. franciscana imported species, respectively during the study period. The final result of this study showed that adaptability of the local species with the local growing natural environments conditions was cost-effective. On the other hand, the results indicated that the suitable species for culturing in any given region is the relevant local species, which preserving the genetic reserves in each region also, the invasion of unwanted species is also prevented.
\end{abstract}

Keywords: Artemia, Ghom province, Ecological effects, Species
Volume 5 Issue I - 2017

\author{
Asadpour Osalou YA, Ganji S, Talebi A, \\ Seidgar M, Mohebbi F \\ National Artemia Research Center, Iranian Fisheries Science \\ Research Institute,Agricultural Research, Education and \\ Extension Organization (AREEO), Urmia, Iran
}

\begin{abstract}
Correspondence: Asadpour Osalou YA, National Artemia Research Center, Iranian Fisheries Science Research Institute, Agricultural Research, Education and Extension Organization
\end{abstract} (AREEO), Iran, Email asadnazlo@yahoo.com

Received: December 06, 2016 | Published: January 20, 2017

\section{Introduction}

Ghom Province is situated in $34.8^{\prime}$ latitude and 52,6' longitude in central Iran and has been classified in terms of climatic identify as per Silianov and Ambroge classification as cold arid and semi-arid region with annual rainfall of $127+/-5 \mathrm{~mm}$ and temperature range of $8.1 \sim 44^{\wedge} \mathrm{C}$ in Jamkaran and Serasuon meteorological stations, which has an average 68 days of freezing weather. According to synoptic stations studies, Ghom Province has dominant southern wind blow with a speed of $6 \sim 9$ knots. The main water supply source of the same is through river and Ghom Road, each $200 \mathrm{MCBM} /$ annum and Jajroud and Shoush rivers of 130 and $80 \mathrm{MCBM} /$ annum, respectively. ${ }^{1,2}$ This study was performed to: compare cysts and biomass production between an imported Artemia species (A. franciscana) with a native species ( $A$. parthenogenetica). Use bare lands in arid and semi-arid regions with salty underground water for Artemia culture.

\section{Materials and methods}

This study was conducted in Shams Abad drainage margin located in Coast of Ghom Lake. In this study, 6 ponds (each 100 sq.m. in area, $\mathrm{h}: 1.5 \mathrm{~m}$ for water filling volume of $1 \mathrm{~m}$ ) were designed and constructed (i.e. each Artemia species in a triplicate repetition). Water filling the ponds was made using the regional drainage waters dissolved with saline of $15 \mathrm{ppt}$ and the salinities of each was adjusted to reach $50 \mathrm{ppt}$. The tested ponds area was totally fenced to prevent from entering the birds and unwanted animals. Protection from entering of unwanted animals was conducted by taking benefit from physical protectors on the inlets of pounds. Fertilizing and enriching the culturing ponds were achieved by standard method. ${ }^{3}$ Nitrate and phosphate and urea fertilizers were used in a dose of $50 \mathrm{~kg} /$ hectare, while chicken fertilizer was also applied. Regional local Artemia cysts and those of Artemia franciscana (of cultured type) were obtained from Ghom Province Lake and A.P.T Company (Vietnam), respectively. The cysts were then hatched and released as the relevant standard method. ${ }^{4}$ In this method, cysts disinfection was conducted by hypochlorite solution ( $200 \mathrm{mg} / \mathrm{lit}$ ) for 20 minutes accompanied by suitable aeration and then they were washed and hatched by a 125 micron lace and freshwater. The hatching method was based on the standard method conducted by Van Stepan et al. ${ }^{4}$

Physicochemical factors such as temperature, oxygen and clarity, $\mathrm{pH}, \mathrm{BOD}$ and COD on all ponds were similar. The environmental factors were measured according to the method explained by Ajorlo \& Abdullah. ${ }^{5}$ Combinations of Artemia partenogenetica and A. franciscana were sampled and determined fortnightly from all the surfaces of the pond. Later on, their biological stages including number of cysts, nauplii and eggs in the female uterine bag were determined. Dry and wet weights of the samples were also examined. By taking benefit from 100 micron fence the biomass per CBM of pond water was measured. The culture period per treatments was 6 months, during which water salinity was kept around $50 \pm 5 \mathrm{mg} / \mathrm{L}$. In order to compensate the water evaporation and penetrability, the relevant reduction was calculated. After completion of culture period, the entire ponds water was demolished by $6 \%$ kozation disinfectant solution to prevent dispersion of Artemia and then the ponds bottoms were completely dried and plowed as suggested by Azari et al. ${ }^{6}$

In order to the grow the species in the further stages a green pond (pond in which Dunaliella sp was grown by standard conditions) was 
applied by taking benefit from chemical and biologic fertilizers of di ammonium phosphate and chicken fertilizer. $50 \mathrm{~kg}$ of urea chemical fertilizer together with $50 \mathrm{~kg}$ di-ammonium phosphate fertilizer and $100 \mathrm{~kg}$ chicken fertilizer mortar were added per time of harvesting microalgae (three times a week). Releasing was conducted as per a rate of 25 nauplii/L of pond water by 100 lit plastic bags and after homogenizing thermal conditions.

\section{Results and discussion}

The factors of each hydrological time periods of the ponds during the culture period were obtained as Table 1 . As can be seen in Table 1, the calcium carbonate $\left(\mathrm{CaCo}_{3}\right)$ was the salt which had the highest concentration in the ponds. Calcium $(\mathrm{Ca}++)$ and magnesium $(\mathrm{Mg}++)$ were two cations with high concentrations, respectively. The lowest values were related to the $\mathrm{NH}_{3}, \mathrm{~N}_{-} \mathrm{NH}_{4}$. Hardness, acidity and salinity evaluated as $9500 \mathrm{mg}$ / lit, $96 \mathrm{mg}$ / lit and 5054ppt, respectively.

Table I ponds hydrological factors during culture period

\begin{tabular}{|c|c|c|c|}
\hline Unit & Factor & Unit & Factor \\
\hline $\mathrm{I} \mathrm{mm}$ & depth & $\mathrm{mg} / 2230 \pm 26$ & $\mathrm{Ca}++$ \\
\hline Clay loam & text & $M g 1215 \pm 15$ & $\mathrm{Mg}++$ \\
\hline $100 \mathrm{ds} / \mathrm{m}$ & ec & $10800 \pm 146$ & $\mathrm{CaCo3}$ \\
\hline $6128 \mathrm{mg} / \mathrm{lit}$ & t.d.s & $\mathrm{I} .4 \pm 0.2$ & $\mathrm{NH} 3$ \\
\hline $9500 \mathrm{mg} / \mathrm{lit}$ & Total hardness & $8.5 \pm 0.56$ & No2 \\
\hline 96 mg/ lit & Total Alkalinity & $7.9 \pm 0.60$ & Acidity \\
\hline 12.3 & P-Po4 & $1.4 \pm 0.15$ & $\mathrm{~N}-\mathrm{NH} 4$ \\
\hline 27.6 & $\mathrm{Cl}$ & $6.5 \pm 0.42$ & No3 \\
\hline 5.54 & So4 & $5.2 \pm 0.21$ & Salinity \\
\hline I 0783 I cell/ lit & & & Total seaweed qty \\
\hline
\end{tabular}

According to Table 2, the highest and the lowest population density of microalgae in the pond were observed for Navicula $s p$. $\&$ Scenedesmus dimorphus, respectively. In total, the highest densities of microalgae in the culture pond were Navicula sp, Nitzschia sp. and Gophonema sp, respectively.

Table 2 Analysis of combination and population density of microalgae produced in pounds during husbandry term

\begin{tabular}{ll}
\hline Cell/lit & Agar type \\
\hline $16002 \pm 201$ & Gophonema sp. \\
$47125 \pm 632$ & Navicula sp. \\
$17883 \pm 145$ & Nitzschia sp. \\
$105 \pm 6.3$ & Scenedes musdimorphus \\
$6503 \pm 101$ & Cymbella sp. \\
$2005 \pm 185$ & Amphora sp. \\
$1959 \pm 18.5$ & Tetraselmis sp. \\
\hline
\end{tabular}

According to the weight estimating results, showed in Table 3 , always with the exception of $75^{\text {th }}$ day, the growth line of $A$. parthenogenetica was $10-40 \%$ higher than A. franciscana. Growth difference on the days 15, 90 and 180 were less but on other days the difference had been growing. Also on the day $75^{\text {th }}$, on the contrary of other days, $A$. parthenogenetica's weight was more than $A$. franciscana.

Most of the A. parthenogenetica nauplii were obtained in $60^{\text {th }}$ day. But then it was reduced up to $180^{\text {th }}$ day. The largest numbers of $A$. parthenogenetica cysts were obtained in $75^{\text {th }}$ day which have decreased until $180^{\text {th }}$ day. The process of gradual reduction during the term had reached the least amount at $180^{\text {th }}$ day (Table 4).
Table 3 Results of napulii weight and growth period population combination

\begin{tabular}{lll}
\hline $\begin{array}{l}\text { A. franciscana Wet } \\
\text { Weight- gr }\end{array}$ & $\begin{array}{l}\text { Husbandry } \\
\text { Term- Days }\end{array}$ & $\begin{array}{l}\text { A. partenogenetica Wet } \\
\text { Weight- gr }\end{array}$ \\
\hline $50 \pm 2.9$ & 15 & 45 \\
$58 \pm 4.5$ & 30 & 32 \\
$55 \pm 7.8$ & 45 & 28 \\
$49 \pm 6.1$ & 60 & 38 \\
$49 \pm 2.3$ & 75 & 53 \\
$41 \pm 3.5$ & 90 & 37 \\
$56 \pm 7.1$ & 120 & 35 \\
$60 \pm 5.0$ & 150 & 47 \\
$63 \pm 10.5$ & 180 & 56
\end{tabular}

Table 4 Results of growth period population combination of Artemia species during the culture period of local Artermia (Artemia partenogenetica)

\begin{tabular}{lll}
\hline No. of Cysts & No. of Nauplii & Day \\
\hline $40 \pm 3$ & $5 \pm 0.35$ & 15 \\
$15 I \pm 10$ & $11 \pm 0.84$ & 30 \\
$231 \pm 24$ & $81 \pm 9.1$ & 45 \\
$254 \pm 30$ & $97 \pm 11.8$ & 60 \\
$354 \pm 29$ & $40 \pm 6.5$ & 75 \\
$158 \pm 17$ & $19 \pm 2.2$ & 90 \\
$168 \pm 20$ & $40 \pm 5.1$ & 105 \\
$170 \pm 25$ & $33 \pm 2.1$ & 120 \\
$155 \pm 2 \mid$ & $22 \pm 1.2$ & 150 \\
$140 \pm 17$ & $11 \pm 3.5$ & 180 \\
\hline
\end{tabular}

Results showed that the highest number of $A$. franciscana nauplii and cysts were obtained at day 45th. This production system of cysts and nauplious was gradually reduced and the lowest rate was reached at $180^{\text {th }}$ day (Table 5).

Table 5 Results of population combination of Artemia species during the culture period of $A$. franciscana

\begin{tabular}{lll}
\hline No. of Cysts & No. of Nauplii & Day \\
\hline $82 \pm 10.2$ & $24 \pm 2$ & 15 \\
$125 \pm 5.8$ & $53 \pm 6.1$ & 30 \\
$226 \pm 14.5$ & $56 \pm 8.5$ & 45 \\
$139 \pm 21.5$ & $41 \pm 2.8$ & 60 \\
$110 \pm 18.1$ & $33 \pm 1.9$ & 75 \\
$103 \pm 12.2$ & $48 \pm 6.2$ & 90 \\
$86 \pm 6.3$ & $38 \pm 6.8$ & 106 \\
$98 \pm 7.1$ & $31 \pm 8.2$ & 120 \\
$90 \pm 10.6$ & $26 \pm 1.3$ & 150 \\
$73 \pm 11.2$ & $25 \pm 1.9$ & 180 \\
\hline
\end{tabular}

The physicochemical factors of the trial pond (table 1), was determined according to the recommended procedure to measure the environmental factors. ${ }^{7}$

Importance of Artemia as the live food source has been recognized as of 1930's in aquaculture. For the time being, shrimp, various decorative and sea and caviar fish husbandry industry depend on Artemia, ${ }^{1,8}$ so that annually, more than 10000 tons of the same is produced and consumed in various countries all over the world. Whereas harvesting the Artemia cysts from global natural water sources such as Great Salt Lake, Urmia Lake and other relevant natural habitats indicate a significant decline due to a variety of reasons, therefore during recent year Artemia culture in pound, ponds and salty lakes and water drainages of the countries, especially those with arid and semi-arid climates is of high importance. Through 
culturing the Artemia species, while optimized utilizing the salty water sources of such countries, the same will be resulted in economic and social development and improves the employment and income conditions. ${ }^{9}$ Using Iranian local and resistant Artemia specie is one of the reasons of achieving success in this regard. Therefore, in this study one of the Iranian local Artemia species together with globally commercial species, namely Artemia franciscana, were assessed in terms of production efficiency under similar culturing conditions. The results indicated that on $5 \%$ probability level $(\mathrm{P}<0.05)$, there is meaningful difference between the two species on the average daily cysts production during the culturing period and the local specie commences cysts generation after summer and in early fall in its natural environment, while it is not true in the case of Artemia franciscana. Such difference on cyst production is meaningful and indicates that $A$. franciscana species loses its cyst generation ration in comparison to local species.

Average number of nauplii during the first two months of husbandry is referred to the fact that local Artemia generates more nauplii than A. franciscana (Tables 4\&5), which shows that the latter has less adaptability to the regional environment and also this situation gives similar results for the living conditions of meta nauplious, juveniles and adults. Local Artemia biomass production level during each term of culturing was equal to 3 ton/hectare, while the figure for $A$. franciscana ia 1.8 ton/hectare (table 3 ) and these figures are agreed with the studies conducted by Browne \& Wanigasekera. ${ }^{10}$ Therefore, development of local species husbandry centers in this region of Iran is more suitable and cost-effective for the economic purposes.

Introduction of non local races to the natural environments both damaging the local races genetic reserves and generates competitive biological interference between the two species. These results had compliance with those of the previous researches. ${ }^{11,9}$

Considering the current conditions in most of the Middle Eastern and Central Asian countries and due to climatic changes, severe water sources loss, culturing Artermia local species for any region by taking benefit from the relevant salty water drainages creates development and increases the local people income as well as increases the employment and capital and decreases pressure implied to the relevant natural habitats. Meanwhile, this study is also agreed with the studies reported by van Stepan et al. ${ }^{4}$ in other continents.

Each kilogram of Artemia is sold for 100 USD on average depending on the quality. ${ }^{2}$ Growing the Artemia cysts in arid and semi-arid areas has a final cost ranging between 30 and 40 USD, and this is a cost-effective aquaculture and results in an increase in country's power in the bottom line of aquaculture industry. Development of rural areas, decreased unemployment and development of agriculture in arid and semi -arid countries having salty and semi-salty water sources is seen as one of the principal stapes in this regard. ${ }^{12}$ In Artemia husbandry certain, water sources are used which have no application for agriculture and/or drinking industry. ${ }^{13}$

Growing Artemia in saline and dead areas in any country with arid and semi-arid climate results in environmental protection (Table 1). Through economic assessments conducted on Artemia culturing showed that such farms are developed in areas exceeding 10000 hectares and the same will have an economic value of 5000 USD per 10 hectares for 10 employees.
Today, in addition to aquaculture industry, Artemia is also used for nanotechnology, pharmaceutics, as a source of human protein, radiobiology and production of pure salt as well as toxicology. ${ }^{4}$

\section{Acknowledgments}

None.

\section{Conflicts of interest}

None.

\section{References}

1. Asadpour Y. A study on the factors affecting in cyst production o Artemia urmiana, Artemia Research Center. 2009;pp.87.

2. Shadrin NV, Batogova EA. Iranian endemic Artemia urmiana Gunther 1890 (Anostraca, Artemidae) in hypersaline lakes of Crimea: new finds. Mar Ecol J. 2009;8(4):40-52.

3. Sorgeloos P, Lavens P, Leger Ph, et al. Manual for the culture and use of brine shrimp Artemia in aquaculture, Artemia Reference Center. University of Ghent, Belgium pp. 2000;319.

4. Van Stappen G, Fayazi G, Sorgeloos P. International study onArtemia: LXIII. Field of Artemia urmiana (Gunther, 1890) population in Urmia Lake, Iran. Hydrobiol. 2009;162:133-143.

5. Ajorlo M, Abdullah R. Assessment of Stream Water Quality in Tropical Grassland using Water Quality Index. Ecopersia. 2014;2(1):427-440.

6. Azari A, Hashim R, AzariTakami G, et al. Effect of Increasing Dietary Prebiotic GroBiotic ${ }^{\circledR}-\mathrm{A}$ Concentration on Growth Performance, Body Indices and Haematological Parameters in Rainbow Trout (Oncorhynchus mykiss) Fingerling. Ecopersia. 2013;1(4):393-406.

7. Kouhpeima A, Feiznia S. Downstream Enrichment in the Transport and Storage of Sediment Fingerprint Properties. Ecopersia. 2013;1(1):7583.

8. Agh N, Van Stappen G, Bossier P, et al. Effects of salinity on survival, growth, reproduction and life span characteristics of Artemia population from Urmia Lake and neighboring lagoons. Pakistan J Biol sci. 2008;11(2):164-172.

9. Abatzopoulos TJ, Amat F, Baxevanis AD, et al. Updating Geographic distribution of Artemia urmiana GUNTER, 1890 (Branhiopoda: Anostraca) in Eurpoe: An integrated and interdisciplinary approach. Rev Hydrobiol. 2009;94 (5):560-576.

10. Browne RA, Wanigasekera G. Combined effects of salinity and temperature on survival ad reproduction of five species of Artemia. L. Sxp. Mar Biol Ecol. 2010;244(1):29-44.

11. Mura G, Nagorskaya LL. Notes on the distribution of the genus Artemia in former USSR countries (Russia and adjacent regions). J Biol Res. 2005;4:139-150.

12. Bagherzadeh-Karimi M, Mammedov R, Fathi-Saghezchi F. Stakeholder Role Analysis for Integrated Management in Protected Areas (Case Study: Urmia Lake, Iran). Ecopersia. 2011;1(2):101-110.

13. Shadrin NV, Batogova EA, Belmonte G, et al. Artemia urmiana Gunther, 1890 (Anostraca, Artemidae) in lake Koyash (Crimea, black Sea): the first finding outside Lake Urmia (Iran). Mar Ecol L. 2008;7(1):3031 . 